\title{
Pilegrimsvandringer $\mathbf{i}$ trosopplæringen og $\mathrm{i}$ samarbeid med andre ${ }^{1}$
}

\author{
Av Hans Morten Haugen
}

Pilegrimsvandringer for barn og unge kan bidra til œrefrykt for skaperverket, kjennskap til lokalmiljøet og åpenhet for troens betydning. Denne artikkelen systematiserer og diskuterer ulike erfaringer med pilegrimsvandringer fra ulike deler av landet, for å gi inspirasjon til andre. Fem typer pilegrimsvandringer identifiseres: (i) Gå og opplev; (ii) oppdag kirken og dens omgivelser; (iii) møt naturens undre; (iv) knytt deg til historien; og (v) åndelig utvikling, inkludert personlig utvikling. Pilegrimsvandringer kan foregå både innenfor trosopplæring og i samarbeid med skole og barnehage.

Hans Morten Haugen (1971), professor i internasjonal diakoni ved VID vitenskapelige høgskole, postboks 184 Vinderen, 0319 Oslo; hans.morten.haugen@vid.no

Det er fruktbart å presentere vandringer som pilegrimsvandringer når de skjer i regi av en menighet eller knyttes til kirker. Ordet pilegrim (latin: peregrinus; fremmed, utenlandsk; består av leddene per (gjennom) og ager (åker)) handler om en person som gjør forsakelser og oppsøker noe nytt. A legge til rette for at deltakerne kommer i kontakt med noe av det som har motivert pilegrimer opp gjennom historien, bør være en motivasjon for pilegrimsvandringer.

En prosjekt- og referansegruppe ved VID vitenskapelige høgskole, Pilegrimsvandring i trosopplæringen, har mottatt trosopplæringsmidler fra Kirkerådet i 2017 og 2018. Gruppen, med ulike erfaringer fra pilegrimsvandringer, har både kartlagt pilegrimsvandringer, delt erfaringer og reflektert rundt ulike pilegrimsvandringer, og skrevet fire inspirasjonsark om slike vandringer, der noen gir nye forslag om hva en vandring kan inneholde.

I prosjektet har vi primært jobbet med pilegrimsvandringer for barn og unge som del av trosopplæring inkludert konfirmasjonstiltak, men pilegrimsvandringer kan også - med noen tillempinger - arrangeres som del av kirkens samarbeid med skole og barnehage og som del av den kulturelle skolesekken. Pilegrimsvandringer for skoleelever og barnehagebarn kommer jeg tilbake til i slutten av artikkelen.

1 Takk til Sturla Sagberg og Alf Rolin for litteraturtips, til forteller Helga Samset (bidrar under vandringer i

Bærum) og forteller Georgiana Keable i Fortellerhuset (arrangerer vandringer i Oslo), og til Thomas Bernhard Thiis-Evensen, Diakonhjemmet Dialog (medlem i prosjektgruppen) og medlemmer av referansegruppen for Pilegrimsvandring i trosopplæringen: Diakon Torun Eskevik Ruud (Hole, Tunsberg) (i første fase av prosjektet var Ivar Solbu, diakon i Sauherad (Agder og Telemark) med), prest Anne Berit Evang (Grorud, Oslo), kateket Anne Marie Sødal (Fræna, Møre), daglig leder Roger Jensen, Pilegrimssenter Oslo, og daglig leder Jane Dahl Sogn, Pilegrimssenter Granavollen. 
Først i denne artikkelen vil jeg kort tematisere læring i naturen generelt og pilegrimsvandringer spesielt, samt hva som er skrevet om barnevandringer og hvordan prosjektet «Pilegrimsvandring i trosopplæringen» kartla pilegrimsvandringer for barn og unge i regi av Den norske kirke eller pilegrimssentrene. Deretter presenteres pilegrimens «sju nøkler», som vil spille en rolle i vurderingen av de ulike vandringene, før kjernen i de fem type vandringer presenteres og deretter sammenlignes og drøftes ved hjelp av de sju nøklene. Til slutt spør jeg om og eventuelt hvordan pilegrimsvandringer kan forvente å få større utbredelse, blant annet gjennom kirke/skole-samarbeid.

\section{Pilegrimsvandringer som lering gjennom erfaring}

Læring gjennom handling - via sanseinntrykk og deltakende formidling - er et anerkjent pedagogisk prinsipp (Dewey 2008; Kolb 1984; se også Howden 2012; Ord og Leather 2011; og Gelter 2007 for læring i naturen). Kolbs erfaringslæringssirkel handler om refleksjoner og begrepsutvikling som svar på erfaringer. Jamissen (2011) vurderer at Kolb blir for deduktiv, og anbefaler at deltakerne tar utgangspunkt i egne konkrete erfaringer, og reflekterer for mulig utprøving av ny praksis - uten at begrepsutvikling alltid er nødvendig. Også dialog om de store spørsmålene anerkjennes som pedagogisk metode i økende grad (Helskog 2015; Helskog 2014; Matusoc og Miyazaki 2014; Kuindersma 2013; Dysthe 1996). Pilegrimsvandringer bygger både på handling, sansing, refleksjon og dialog om de store spørsmålene (Jensen 2014; se også Haga 2016).

Pilegrimsvandringer bygger på et helhetlig syn på mennesket (både fysiske, psykiske og åndelige dimensjoner; se Kolbjørnsrud 2012; Holm 2015), og artikkelen vil undersøke hvordan et slikt syn kan fremmes i den læringsprosessen som en pilegrimsvandring er. Selv om endret forståelseshorisont kan være utfallet av en godt tilrettelagt pilegrimsvandring, er det for ambisiøst å ta utgangspunkt i teorier om transformerende læring for å vurdere en pilegrimsvandring som foregår over noen timer. Transformerende læring handler om at nye erfaringer og kunnskaper skaper dissonans i ens tidligere forståelseshorisont, slik at ny refleksjon og innsikt kan fasiliteres gjennom dialog og samhandling (Hatlevik 2018). Gjennom klare «oppgaver» under vandringen, tid til egenrefleksjon og gode samtaler i etterkant er likevel slik transformerende læring som resultat av en pilegrimsvandring fullt ut mulig.

\section{ResSURSER OG KARTLEgGing}

Mange ressurser om pilegrimsvandring er utviklet (Bakken 2017; Jensen 2014; Hestnes og Pettersen 2011). Disse retter seg primært til voksne. To publikasjoner om barne- og ungdomsvandringer finnes: Jordvenn (Ekre 2018) - som forklarer innholdet i 10 ulike vandringer ute, der noen ender i kirka - og Tro $i$ 
bevegelse. Trosvandringer for små og store (Leikvoll 2005), som forklarer innholdet i over 20 ulike vandringer, hovedsakelig i kirkerommet, og noen i forbindelse med gudstjenester.

For de litt større ungdommene finnes ressurser utviklet for På sporet - Den norske kirkes breddetiltak innenfor trosopplæring, som retter seg inn mot ungdom på vei mot å bli myndige - og én bokutgivelse som omhandler reiser for ungdom til pilegrimsmål i og utenfor Norge (Eriksen og Herefoss 2015). To av reisemålene som løftes fram i boken, er Selje (St. Sunniva) og Trondheim (St. Olav).

I prosjektet «Pilegrimsvandring i trosopplæringen» var det først viktig å kartlegge og vurdere pilegrimsvandringer, både de som gjennomføres langs hovedleden til Nidarosdomen og andre steder. Vi ringte og sendte eposter til både trosopplæringsrådgivere og personer med ansvar for pilegrimsvandringer ved bispedømmekontorene, som visste noe om hvor ulike pilegrimsvandringer var fors $\emptyset$ kt. Deretter ringte vi til noen av menighetene og personer som var engasjerte i pilegrimsarbeid på ulike måter. Vi har ikke gjort en fullstendig kartlegging. Referansegruppen har også diskutert hvordan pilegrimsvandring $\mathrm{i}$ dag fungerer med ulike type samarbeid, hvor mye vekt som legges på refleksjonsarbeid - mellom stoppene på vandringen - og hvilke muligheter samarbeid kirke-barnehage og kirke-skole kan gi. De ulike deltakernes tilbakemeldinger er formidlet via medlemmene i referansegruppen, og kommer til uttrykk i inspirasjonsarkene, som vi skal se under.

Fem hovedtyper pilegrimsvandringer presenteres her, og vi kommer tilbake til dem:

1 Gå og opplev

2 Oppdag kirka og omgivelsene

3 Møt naturens undre

4 Knytt deg til historien

5 Åndelig utvikling, inkludert personlig utvikling

En vandring kan plasseres i mer enn en av disse typene. Ingen av de fem pilegrimsvandringene løfter fram eksplisitt kristen forkynnelse, men alle gir godt rom for slik formidling.

\section{Pilegrimens sJu nøkler}

Som innsteg til drøftingen vil jeg kort presentere pilegrimens sju nøkler: langsomhet - frihet - enkelhet - bekymringsløshet - deling - stillhet åndelighet (Lindström 2015; Lindström 2007; Pettersen 2013; Pilegrimssenter Granavollen 2017). I presentasjonen av de ulike vandringstypene nedenfor vil jeg vurdere hvorvidt vandringene kan gjøre bruk av eller legge til rette for disse 
sju nøklene. Det er Lindström selv som har utviklet disse sju nøklene, ut fra sine erfaringer gjennom 40 år med pilegrimsarbeid, både i menighet og ved Vadstena kloster, hvor han etablerte pilegrimssenteret.

Langsomhet kan skje i det ytre og i det indre, og en pilegrimsvandring fors $\varnothing$ ker å legge til rette for at den enkelte kan få nok tid til å kunne tenke gjennom viktige hendelser eller beveggrunner.

Frihet er noe mer enn valgfrihet stilt overfor en rekke konkurrerende tilbud, men en reell frihetsfølelse fra hverdagens krav om blant annet prestasjon og synlighet.

Enkelhet handler om å fokusere på det viktigste i livet, og det viktigste i livet er faktisk gratis! En enkel livsstil gir mindre å bekymre seg over, og kan gi frihetsfølelsen omtalt over.

Bekymringsløshet er sentralt i Jesu bergpreken (Matt 6) og slettepreken (Luk 12) - og i Filipperbrevet 4 løfter Paulus fram en svært inspirerende livsvisjon som handler om å finne glede i Gud («Herren») og la denne gleden prege oss i vår omgang med andre. Uansett hvor lett det er å praktisere denne visjonen, gir den håp.

Deling handler om å erkjenne at vi er avhengige av hverandre og at vi alle kommer lettere gjennom både livet og en pilegrimsvandring dersom vi klarer å dele. Selv om kristendommen løfter fram den enkeltes ansvar, både overfor den enkelte og overfor Gud, er det kristne livet et liv i fellesskap - og en pilegrimsvandring gir et lite glimt av dette.

Stillhet og uberørt natur er av det tilreisende og pilegrimer som kommer til Norge mest vet å sette pris på; for erfaringer med stillhet i naturen inspirert av keltisk åndelighet; se Hellesnes (2018). Minst én, helst flere etapper i en pilegrimsvandring bør skje i stillhet.

Åndelighet er den av de sju nøklene som trenger mest avklaring. Det er feil å knytte åndelighet utelukkende til noe religiøst eller kristent. I det norske språket har vi eksempelvis ordet åndsverk, som uttrykk for menneskelig skaperevne. Når ordet åndelighet brukes i dag, er ofte ordet «eksistensiell» også med; det vil si at man søker å sette sitt liv inn i en større sammenheng, uansett om Gud inngår eller ikke inngår i denne sammenhengen. En pilegrimsvandring kan fremme åndelig utvikling, og slik bidra til livsmestring og livstolkning. Selv om åndelig utvikling kan være vanskelig å fange inn i én definisjon (Haugen 2015:223-226), kan denne fungere: «Åndelig utvikling handler om ens relasjoner til seg selv, andre, verden/naturen, og det transcendente - og som bidrar til å skape helhet» (Fisher 2009:273; se også Haugen 2018 og Jensen 2015:116). Det transcendente vil for en religiøs person handle om Gud, mens for en ikke-religiøs person kan det handle om ulike sider ved mennesket, som kreativitet, samvittighet eller forståelser av én menneskehet. 
Disse sju nøklene vil brukes for å vurdere de ulike pilegrimsvandringene, og først presenteres disse.

\section{DE FEM TYPER VANDRINGER}

Gjennom samtalene i prosjektet Pilegrimsvandring i trosopplæringen identifiserte vi fem typer av vandringer. Først presenteres hovedinnholdet i disse ulike vandringene; deretter vurderes disse ut fra fire av pilegrimens sju nøkler.

\section{Gå og opplev}

Denne typen vandring gir mest mulig rom for at deltakerne selv former vandringen, men det skjer også bevisst tilrettelegging fra lederne. Ofte er en kirke et mål også for disse vandringene, men deltakerne møter kirken slik de møter andre ting langs veien; med undring. Barnevandringer i regi av Pilegrimssenter Granavollen er eksempel på slike vandringer. Pilegrimssenteret kan også bidra til barnevandringer lokalt i hele regionen (Ringerike, Hadeland og Toten).

Barnevandringer skjer også som del av Den kulturelle skolesekken i denne regionen og i Oslo (se under), og på Granavollen er disse vandringene nokså korte: to kilometer, og vandringene avsluttes med at barna går rundt søsterkirkene på Granavollen. Som for andre vandringer ved Granavollen nevnes under vandringen pilegrimens sju nøkler: langsomhet - enkelhet - frihet - bekymringsløshet - deling - stillhet - åndelighet (Pilegrimssenter Granavollen 2017).

Inspirasjonsarket om barnevandringer (Pilegrimsvandring i trosopplæringen 2019a) vektlegger hvordan det kan legges til rette for undrings- og refleksjonsprosesser med barn i barnehager. Jane Dahl Sogn ved Granavollen skriver i inspirasjonsark 2:

Pilegrimsvandring er en helt unik, en helt fantastisk arena, for gode samtaler og meningsfylt dialog med barn og unge! Jeg har tidligere jobbet $i$ Jevnaker menighet, men aldri opplevde jeg der den samme åpenheten, nysgjerrigheten og den lave terskelen for å snakke sammen om nare og personlige tema. Aldri var det så lett å snakke om religion som det er via pilegrimstematikken. Og hvilket behov - barn og unge bobler over av spørsmål, av erfaringer, av følelser, av nysgjerrighet, av et behov for voksne som svarer, har tid, er åpne og cerlige, ser dem. Ja, jeg har ikke ord gode nok for hva jeg oppleverdet er så meningsfylt, det oppleves så berikende! Både jeg og mine kollegaer både gir og får kunnskap - dialogen er SÅ bra! Flere burde gjøre dette - og Den norske kirke burde gripe denne muligheten (Pilegrimsvandring i trosopplaringen 2019a).

\section{Oppdag kirka og omgivelsene}

En enda kortere vandring kan gjennomføres både utenfor og inne i kirken. To slike vandringer er beskrevet i Jordvenn (Bjørdal 2018; Vormeland og Seljås 2018). Bjørdal, kateket i Ås kirke på Toten beskriver en samling for 8-12-åringer kalt 
«sol», bestående av en vandring med sju stasjoner: Starten skjer i avstand til kirken; deretter ved kirkeporten; inn i kirken, sitte bakerst; ved alteret; vandring i kirken; gudstjeneste; måltid. Her er fortroligheten med kirkerommet sentralt.

Vormeland og Seljås, diakon og prest i Eidsberg, beskriver en konfirmantvandring som tar utgangspunkt i Kristuskransen. Også andre vandringer bruker Kristuskransen (Pilegrimsvandring i trosopplæringen 2019b). For å fremme vandring i stillhet vil Kristuskransen være til hjelp. Nattperlen, som åpner for å snakke om det som er trist, skaper ifølge dem umiddelbar interesse hos ungdom. Gudsperlen, jeg-perlen og dåpsperlen er også gode å bruke, i tillegg til stillhetsperlene. Vandringen har start og slutt på kirketrappen, og skjer i umiddelbar nærhet til kirken, og knytter seg både til naturelementer og ulike andre symboler. Tanken med å legge en pilegrimsvandring i nærhet til kirken er å gi fortrolighet med og lyst til å oppsøke kirken.

Lengre konfirmantvandring er også gjennomført i Lunner, av trosopplærer Trond Hem Stenersen. I denne vandringen spikker alle konfirmantene sin egen stav. I konfirmantvandringen i Fræna, som også har en lengre vandring, bærer konfirmantene en sten som de så legger på en «påkastrøys».

Det å for første gang se kirken som er målet for pilegrimsvandringen, er en sentral pilegrimserfaring, og stedet man første gang ser målet for vandringen, omtales som «feginsbrekke» eller gledesbakke. Her er det vanlig at pilegrimen stopper opp i takknemlighet over å ha nådd målet.

\section{Møt naturens undre}

Flere vandringer som handler om å knytte oss til naturen, er beskrevet i Jordvenn (Ekre 2018). Alle vandringer, både lange og korte, søker å bevisstgjøre deltakerne på vårt forhold til naturen, men likevel er det viktig å løfte fram naturundring som et særpreg ved noen av vandringene.

Ved de ulike stasjonene samles inn eller berøres vann, jord, planter/blomster/ pinner til kors, og luft. Noen vandringer har også med ild (både sol og bål) og vind. Det går altså an å inkludere alle de fire grunnelementene vann, jord, ild og luft $i$ en pilegrimsvandring.

En vandring ved havet er utviklet av Knut-Magnus Nesse, sogneprest i Kinn, og handler om å lytte til naturen, plukke søppel i havet og skape fellesskap rundt måltid; med avslutning ved Selje kyrkje, med beretning om St. Sunniva (Nesse 2018).

I tillegg omfatter klimapilegrim-satsingen i regi av blant andre Kirkens Nødhjelp, både i 2015 og i 2018-2019, egne ressurser for vandringer med barn og ungdom (Klimapilegrim 2015). Her løftes fram vann, flukt, ansvar og håp. Dersom Kristuskransen brukes, er det naturlig å løfte fram den grønne perlen, som finnes i den nye utgaven av Kristuskransen. 


\section{Knytt deg til historien}

Å følge deler av den historiske pilegrimsleden er den vanligste formen for vandring for barn. Alle 6.-klassinger i Bærum går fra Haslum middelalderkirke mot Lommedalen (Aftenposten 2009), og 6.- klassinger i noen Oslo-skoler går over Gjelleråsen mot Nittedal (Vårt Land 2018 og Akers Avis Groruddalen 2018). Begge samarbeider med Den kulturelle skolesekken. I Bærum møter konfirmantene en kateket i Haslum middelalderkirke. Deretter er det frivillige som leder selve vandringen, og de møter $\mathrm{i}$ en hytte en forteller, som beretter et folkeeventyr, om Olav den Hellige, historien «Lysflammen» i boken Kristuslegender av Selma Lagerløf, og litt om pilegrimserfaringer. Fortelleren skriver i en epost: «Pilegrimsvandringen har fått fantastisk tilbakemelding hvert eneste år...». I Oslo inviteres menighetene i Groruddalen til å være med, men menighetene er ikke ansvarlige. På vandringene i Oslo ledes vandringene av profesjonelle fortellere som bruker eldre pilegrimsklær og -gjenstander. Også her er tilbakemeldingene svært gode.

Det at Bærum og Oslo løftes fram, er ikke tilfeldig. I Bærum har anslagsvis 25 tusen 6.-klassinger gått pilegrimsleden. I Oslo ble vandringen initiert av Fortellerhuset, og fra 2008 ble det inngått et samarbeid med Den kulturelle skolesekken og deretter med Oslo Bispedømme og det som nå heter Groruddalen prosti. Samtidig kunne en rekke andre vandringer som søker å knytte an til historien, vært omtalt. Fortellerhuset er også ansvarlige for pilegrimsvandringer i Vestfold, og langs hele hovedleden og andre steder i landet foregår det vandringer, også for barn og unge (Pilegrimsvandring $\mathrm{i}$ trosopplæringen 2019c).

En annen vandring som er verdt å nevne, er tilbudet fra Pilegrimspresten i Oslo om en konfirmantvandring fra Gamlebyen, med en avslutning i Gamle Aker kirke (Pilegrimssenter Oslo 2018).

\section{Åndelig utvikling, inkludert personlig utvikling}

De vandringene som er trukket fram så langt, er ofte av relativt kort varighet, der de lengste varer anslagsvis fire timer. Prosesser underveis kan gi en mulighet for indre refleksjon og bearbeiding hos den enkelte og i gruppen, og prosessen kan ofte bli bedre dersom det gis noe videre tidsrammer.

Slike refleksjonsprosesser kan bidra til å forløse undring og erkjennelse hos den enkelte, og kan også brukes som hjelp i konfliktløsning (Helskog 2015; 2014).

En forankring i åndelig utvikling handler om å fremme relasjoner og mening, og knytter sammen åndelige og eksistensielle temaer. Som en hjelp til å tenke eksistensielt kan det være gunstig å oppgi et tema for refleksjonen. Vi har imidlertid erfaringer med at åpne prosesser verdsettes av deltakere, dersom de blir oppfordret til å tenke på det de har erfart som positivt.

I Inspirasjonsark 4 løftes to spørsmål fram ved slutten av to av stoppene i 
vandringen, eksempelvis: «Hva er kjærlighet?/ Hva er det å tro på noe?» og «Hvilke positive/viktige hendelser gjør meg til meg? / Hva kan jeg bety for andre?» (Pilegrimsvandring i trosopplæringen 2019d). Det er viktig at det bare er ett tema som løftes fram ved hvert stopp.

Dersom det er tid til en samling mot slutten av vandringen, kan det være mulig å be alle deltakerne om å presentere et allment spørsmål gjennom det konkrete og selvopplevde. Deretter velges ett av disse spørsmålene som utgangspunkt for en samtale mellom alle deltakerne.

Lederen sin oppgave under en slik avsluttende deling er å sørge for at ingen blir for dominerende, og at alle kommer til orde. Opplagt vil en slik prosess kreve grupper som ikke er for store, og for den avsluttende samtalen vil ti personer være et passende antall. Det er vanskelig å trekke fram en vandring for barn og unge som har et slikt preg, men På sporet-vandringer - et av breddetiltakene i Den norske kirkes trosopplæring - kan gi muligheter.

\section{Fellestrekk og ulikhet}

De ulike vandringene kan forstås i lys av pilegrimens sju nøkler: langsomhet enkelhet - frihet - bekymringsløshet - deling - stillhet - åndelighet.

De tre første ikke er så enkle å gå dypt inn i når vi har å gjøre med vandringer som foregår over et kort tidsrom. Langsomhet, enkelhet og frihet vil antakelig bare oppleves for den enkelte på noe lengre vandringer. De fire andre er imidlertid høyst relevante å tematisere. Med utgangspunkt i bekymringsløshet, deling, stillhet og åndelighet vurderes de ulike typer vandringer for barn og unge.

Bekymringsløshet: Ordet bekymringsløs kan brukes i ulike sammenhenger. En betydning handler om å ta ting som de kommer, og ikke tenke på konsekvensene, altså en form for lettsindighet. En vesentlig annen betydning handler om å ha en dypere forankring for sitt liv, og ikke fă uro over det man ikke mestrer eller får til, altså en form for dyptfølt trygghet. Mange av vandringene bruker Kristuskransen, og en av perlene er den blå bekymringsløshetens perle. Vi trenger imidlertid en bedre forståelse av bekymring.

Negativ bekymring kan enten være knyttet til det nære - eksempelvis endringer som truer ens posisjon - eller til det som oppleves som langt unna - eksempelvis klimaendringer eller at arter forsvinner. Jeg tar for meg de store globale spørsmålene.

Denne type bekymring kan være vanskelig å bearbeide på en pilegrimsvandring. Samtidig kan en slik vandring løfte fram hvordan Gud har omsorg for mennesker og alt det skapte. Dersom en vandring fokuserer for sterkt på klimaendringer eller havfors $\emptyset$ pling, kan det være vanskelig å samtidig fremme den gode bekymringsløsheten, som altså handler om en dyptfølt trygghet. En vandring for barn og unge som søker å løfte fram naturens undre og derigjennom 
verdsette alt liv, kan fremme håp og engasjement. Likevel kan det være en krevende balanse mellom en for dyster virkelighetsbeskrivelse og en håpsformidling som blir troverdig.

Mange barn og unge opplever bekymring for at de ikke strekker til, er pen nok eller populær nok. Bekymringsløshet som dyptfølt trygghet er antakelig vanskelig å oppnå på en kort vandring, men jeg tror det er mulig at en pilegrimsvandring kan starte gode tankeprosesser.

Deling: Pilegrimsvandring gir muligheter til å dele erfaringer, beretninger og personlige historier. Slik deling skaper muligheter for samhandling på et dypere plan enn det de unge vanligvis erfarer. Samtidig er varigheten $i$ en vandring ofte begrensende for hvor mye deling som faktisk er mulig å få til.

Pilegrimsmotivet er minst like sterkt $i$ andre deler av verden og $i$ andre religioner som i den vestlige utgaven av kristendom. Samtidig som at det å åpne for ulike perspektiver på pilegrimsvandring er positivt, er det viktig at det særlige formålet for den aktuelle vandringen kommer tydelig fram, både ved innledningen og ved de ulike stoppene.

Dersom tiden tillater det, anbefales en samtale mot slutten av en vandring, der alle blir bedt om å dele tanker eller noe man har lært under vandringen, men det ideelle vil være at deltakerne blir enige om et tema å samtale om, som deltakerne velger ut fra den enkeltes allmenne spørsmål (Pilegrimsvandring i trosopplæringen 2019d).

Stillhet: En pilegrimsvandring bør ha minst én etappe der deltakerne vandrer i stillhet. Hvor lenge stillheten varer, vil avhenge av hvor gamle deltakerne er, og delvis hvilke oppgaver de er blitt gitt ved forrige stopp. Ulike personer vil oppleve stillheten ulikt, og man kan også bes om å kjenne på noe utenfor seg selv, som vinden, eller noe ved egen kropp, som føttene eller pusten.

For å løfte fram stillhet vil bruk av Kristuskransen være nyttig, som ytterligere forklart i inspirasjonsarkene (Pilegrimsvandring i trosopplæringen 2019b; Pilegrimsvandring i trosopplæringen 2019d). Kristuskransen er svært egnet til å samle tankene, enten det er på Gud, seg selv eller den naturen som omgir oss.

Åndelighet: Åndelig utvikling, forstått som en utvikling av de fire relasjonene (meg, andre, naturen, det transcendente) tar tid å fremme, men en pilegrimsvandring kan gi viktig næring.

Det er imidlertid viktig å være oppmerksom på at ordet åndelighet ikke gir umiddelbart positive konnotasjoner hos de fleste nordmenn. Unders $ø$ kelsen Being Christian in Western Europe viser at bare en av ti nordmenn opplever seg selv som både religiøs og åndelig, og en av seks nordmenn opplever seg som religiøs, men ikke åndelig (Pew Research Center 2018:122). Den absolutt høyeste andelen (62 prosent) regner seg som verken religiøs eller åndelig (Pew Research Center 2018:122). Andelen som omtaler seg som kristne, er 52 prosent, og dette 
tallet omfatter 38 prosent som regner seg som «ikke-praktiserende kristne» (Pew Research Center 2018:7).

Disse tallene innebærer ikke at den sjuende pilegrimsnøkkelen bør hete noe annet enn «åndelighet», men for barn og unge må ordet åndelig antakelig gis mer konkret meningsinnhold for å skape gjenkjennelse og gi mening. Når barna deltar i vandring for å oppdage kirka og omgivelsene rundt, er det nettopp det konkrete i kristne praksiser og ritualer som gir mening.

Som avslutning på denne drøftelsen kan vi se at pilegrimsvandringen bør knytte an til håndgripelige og jordnære ting, samtidig som det bør være rom for undring og utforskning av de store spørsmålene i tilværelsen, inklusive undring rundt egen utvikling og rolle.

\section{Kan vandringer få større utbredelse?}

Utvilsomt er vandringer blitt langt mer utbredt (Aftenposten 2017), men det er fortsatt omtrent like mange nordmenn som går pilegrimsleden til Santiago de Compostela i Spania som det totale antall vandrere til Trondheim og Nidarosdomen (ABC Nyheter 2015; NRK 2017).

Nærhet til naturen, interesse for historien og bedre folkehelse, både psykisk og livsstilmessig, er opplagte motivasjoner for hvorfor folk ønsker å gjennomføre pilegrimsvandringer (Fortellerhuset 2019). Samtidig er det ingen grunn til å tone ned den kristne forankringen for pilegrimsvandring. I samband med arbeidet med en ny langtidsplan for den nasjonale pilegrimssatsingen løftet daværende kulturminister Helleland fram fire sentrale elementer i en ny plan, der det ene var tro, i tillegg til opplevelse, næring og kultur (Nasjonalt pilegrimssenter 2018).

Ikke alle satsinger på vandringer innenfor trosopplæringstiltak har vært like vellykkede. Som ett av seks « nasjonale breddetiltak» i trosopplæringen (Kirkerådet 2018), har På sporet ikke blitt fullført alle steder hvor det er blitt lansert. Navnet På sporet ble valgt også fordi man erfarte at ordet pilegrim ikke fungerte for ungdom. Bakgrunnen kommer delvis fra et trosopplæringstiltak og en bok i regi av KRIK: På sporet av noe ekte (Holm 2013). Kurs holdes i noen menigheter, men navnet «På sporet av noe ekte» er i en menighet nylig blitt erstattet av «VERTIAS - å s $\emptyset$ ke helhet» (Nordberg menighet 2018).

Da På Sporet ble lansert som breddetiltak i 2016, ble tre menigheter valgt ut i hvert bispedømme som fors $\emptyset$ ksmenigheter. Mange av disse rapporterer at det har vært en utfordring å få god nok rekruttering; som regel skyldes rekrutteringsproblemer at det er lite eller utydelig kommunikasjon om hva tiltaket omfatter.

Med mulig unntak for pilegrimsvandringen i Ringerike prosti, som promoteres som en del av trosopplæringen (Hole kirkelige fellesråd 2018; 2019), kjenner vi ikke til menigheter som mener å ha lyktes godt i å gjennomføre vandringer 
med stor deltakelse fra eldre ungdommer. Noen ganger vil speidergrupper med eldre ungdommer kunne gi muligheter, men eldre speidere utgjør sjelden en stor andel av ungdom i sine respektive årskull.

Konfirmantvandringer er ofte enklere å få rekruttering til, sammenlignet med andre vandringer i menighetsregi. De regionale pilegrimssentrene melder at det er lett å rekruttere yngre barn for vandringer, der samarbeidet retter seg mot skolene. Dette bringer oss over på hvilke muligheter samarbeid kirkebarnehage og kirke-skole kan gi.

\section{Muligheter}

For alle pilegrimsvandringer kan det være bra å samarbeide med flere andre, som kulturkontoret og lokale turlag. For pilegrimsvandringer med barn og unge er det to hovedmuligheter for planlegging og gjennomføring: Som del av trosopplæringstiltak, inklusive konfirmasjonsforberedelse, eller i samarbeid med skole eller barnehage, gjerne gjennom Den kulturelle skolesekken. Direkte samarbeid med Den norske kirke er ikke mulig gjennom Den kulturelle skolesekken, men samarbeid om pilegrimsvandring kan organiseres på annet vis.

Barnehage og skole skal etter sine formålsparagrafer gi barn og ungdom historisk og kulturell innsikt og forankring. Rammeplan for barnehagen nevner også en åndelig dimensjon og rommet for eksistensielle spørsmål (Utdanningsdirektoratet 2017; se også Kuindersma 2013; Schjelderup og Olsholt 2013), mens den nye overordnede delen av skolens læreplanverk trekker fram både historisk og kulturell innsikt og forankring (kap 1.2) og «Verdivalg og betydningen av mening i livet ...» (kap 2.5.1). Dette kan motivere for pilegrimsvandringer som tilbud til skole og barnehage. Her må det nevnes at samarbeid med skoler og barnehager legger føringer på hva som kan formidles, men det er mange elementer av den kristne arven og store spørsmål, lengsel og undring som kan ha sin plass. Dette skjer på vandringer med barnehager eller med skoleklasser, slik Pilegrimssenter Granavollen gjør i et samarbeid gjennom Den kulturelle skolesekken. Ut fra de erfaringene som Jane Dahl Sogn ved Pilegrimssenter Granavollen formidlet over, burde også samarbeid om pilegrimsvandring prioriteres av menighetene - for å gi gode (lærings-) opplevelser med mulighet for samtaler og undring rundt de store spørsmålene.

God planlegging og det å finne gode ressurspersoner og gode vandringsveier er avgjørende. Selve gjennomføringen av pilegrimsvandringen kan gjøres av frivillige i menigheten. For at vandringene skal bli best mulige, kan man lære av andres erfaringer, som Jordvenn-nettverket i regi av IKO.

Iallfall fire av de sju pilegrimsnøklene kan inspirere og gi retning $i$ arbeidet med pilegrimsvandringer for barn og ungdom, men vi har sett at den berømte dørstokkmila også gjør seg gjeldende i slike pilegrimsvandringer. Det kan være 
vanskelig å rekruttere til det som ikke er en del av et obligatorisk opplegg, men personene vi har snakket med, formidler at deltakerne uttrykker stor tilfredshet etter å ha deltatt i pilegrimsvandringer. Ofte husker ungdommer godt en vandring de har gjennomført flere år tidligere. Dette viser at deltakerne har hatt positive erfaringer.

\section{LitTERATUR}

$A B C$ Nyheter. 2015. «250.000 på vei til Santiago de Compostela» (21. mars)

Aftenposten. 2017. «Stadig flere går pilegrimsvandringer i Norge - en tredjedel er tyskere» (25. juli).

Aftenposten. 2009. «Legg ut på pilegrimsferd» (17. juni).

Akers Avis Groruddalen. 2018. «10 år med pilegrimsvandring» (21. september).

Bakken, Arne. 2017. Pilegrim - folk kirke kosmos. Oslo: Nygaard Forlag

Bjørdal, Gunnhild Hauge. 2018. «Trosopplæringstiltak. Sola i Ås kirke». I: Ekre, Eldbjørg Leineb $\emptyset$ (red): Jordvenn - venn med hele skaperverket, Oslo: IKO-Forlaget, s. $86-91$.

Dewey, John. 2008. «Å gjøre en erfaring». I: Kjersti Bale og Arnfinn B $\emptyset$-Rygg (red): Estetisk teori. En antologi. Oslo: Universitetsforlaget, s. 196-213 [oversettelse av «Art as experience» fra 1934].

Dysthe, Olga (red.). 1996. Ulike perspektiv på leering og læeringsforskning. Oslo: Cappelen akademisk.

Ekre, Eldbjørg Leinebø (red). 2018. Jordvenn - venn med hele skaperverket, Oslo: IKO-Forlaget.

Eriksen, Magnhild Søsveen og Vija Herefoss (red). 2015. Påleting etter tro. Dannelsesreiser med ungdom, Oslo: IKO-Forlaget.

Fisher, John. 2009. «Getting the balance: assessing spirituality and well-being among children and youth», International Journal of Children's Spirituality 14(3), s. 273-288.

Fortellerhuset. 2019. Story Walks in the Natural World. [online]. Tilgjengelig: https:// www.immateriellkulturarv.no/bidrag/story-walks-in-the-natural-world juni 2019).

Gelter, Hans. 2007. «Friluftsliv as Slow Experiences in a Post-modern «Experience» Society». I Bob Henderson og Nils Vikander (red): Nature First: Outdoor Life the Friluftsliv Way. Toronto: Natural Heritage Books, s. 37-46.

Haga, Joar. 2016. «Bokmelding av Roger Jensen, Pilegrim. Lengsel, vandring, tenkning - før og nå». Teologisk Tidsskrift 5(1), 97-100.

Hatlevik, Ida K. R. 2018. «Transformativ læring. Hva er det, og hva kan det bidra med i lærerstudenters kompetanseutvikling?» Uniped 41(4), s. 384-400.

Haugen, Hans Morten. 2018. «It is Time for a General Comment on Children's Spiritual Development», International Journal of Children's Spirituality 23(3), 306-322. 
Haugen, Hans Morten. 2015. «Trosopplæring, åndelig utvikling og diapraksis. Arbeid i flerkulturelle lokalsamfunn», Prismet 66(4), s. 221-233.

Hellenes, Ola. 2018. «Friluftsliv, religion og stillhet», Prismet 69(4), s. 319-329.

Helskog, Guro Hansen. 2015. «The Gandhi Project. Dialogos philosophical dialogues and the ethics and politics of intercultural and interfaith friendship», Educational Action Research 23(2), s. 225-242.

Helskog, Guro Hansen. 2014. «Moving out of conflict into reconciliation. Bildung through philosophical dialogue in intercultural and interreligious education», Educational Action Research 22(3), s. 340-362.

Hestnes, Torbjørn og Margun Pettersen. 2011. Pilegrim i Stavanger. Pilegrimens 7 nøkler langsomhet frihet enkelhet bekymringsløshet stillhet fellesskap åndelighet [online]. Tilgjengelig: https://www.yumpu.com/no/document/read/18507808/pilegrim-istavanger-hefte-utarbeidet-av-torbjrn-hestnes-pasjon (13. juni 2019).

Hole kirkelige fellesråd. 2019. Det skjer. Pilegrimsgudstjeneste i Hole kirke. [online]. Tilgjengelig: https://detskjer.ringbillett.no/arrangement.aspx?id=680 (13. juni 2019).

Hole kirkelige fellesråd. 2018. Trosopplæringen våren 2018. [online]. Tilgjengelig: https://m.hole.kirken.no/artikkel/article/816101 (13. juni 2019).

Holm, Toril Elin K. 2015. Pilegrimsvandring og åndelig helse. Et kvalitativt studie av pilegrimsvandringens betydning for åndelig helse, Masteroppgave Diakonhjemmet Høgskole [nå VID]. Oslo: VID vitenskapelige høgskole

Holm, Vegard. 2013. På sporet av noe ekte, Oslo: Luther.

Howden, Eric. 2012. «Outdoor experiential education: Learning through the body», New Directions for Adult and Continuing Education 2012(134), s. 43-51

Jamissen, Grete. 2011. «Om erfaringskunnskap og læring: Et essay», Uniped 34(3), s. $30-40$.

Jensen, Roger. 2015. «Leder: Inn i sin tid», Prismet 66(3), s. 115-117.

Jensen, Roger. 2014. Pilegrim. Lengsel, vandring, tenkning - før og nå. Oslo: Novus.

Kirkerådet. 2018. Nasjonale breddetiltak. [online]. Tilgjengelig: https://ressursbanken. kirken.no/nb-NO/sokeside/?query=Nasjonale+breddetiltak\&cat=92 (13. juni 2019).

Klimapilegrim. 2015. Sammen mot Paris. Supplerende materiell til vandringer i alderssammensatte grupper. [online]. Tilgjengelig: https://www.klimapilegrim.no/ressurser (gå til Barn og ungdom) eller http://gammel.gronnkirke.no/doc//Ressursmateriell/ Klimapilegrim/Klimapilegrim_hefte.pdf (13. juni 2019).

Kolb, David A. 1984. Experiential Learning. Experience As The Source Of Learning And Development. Englewood Cliffs, NJ: Prentice Hall.

Kolbjørnsrud, Mari. 2012. Helende vandring? En kvalitativ studie av hvordan pilegrimsvandring kan gi et sceregent bidrag til diakonien, drøftet $i$ lys av kristen holistisk spiritualitet, Masteroppgave MF. Oslo: MF vitenskapelig høyskole 
Kuindersma, Henk (red). 2013. Powerful Learning Environments and Theologizing and Philosophizing with Children. Kassel: Kassel University Press [e-bok].

Leikvoll, Solveig. 2005. Tro i bevegelse. Trosvandringerfor småog store. Oslo: IKO-Forlaget. Lindström, Hans-Erik. 2015. Pilgrimens sju nyckelord. Inspiration för din livsresa. Stockholm: Libris.

Lindström, Hans-Erik. 2007. Pilegrimsliv - en håndbok for vandrere. Oslo: Verbum.

Matusoc, Eugene og Kiyotaka Miyazaki. 2014. «Dialogue on Dialogic Pedagogy», Dialogic Pedagogy. An International Online Journal Vol. 2, DOI: 10.5195/dpj.2014.121.

Nasjonalt pilegrimssenter. 2018. Ny langtidsplan skal styrke pilegrimssatsingen. [online]. Tilgjengelig: http://nasjonaltpilegrimssenter.no/aktuelt/ny-langtidsplanskal-styrke-pilegrimssatsingen (13. juni 2019).

Nordberg menighet. 2018. VERITAS - å søke helhet. [online]. Tilgjengelig: https://kirken. no/nb-NO/fellesrad/kirkeneioslo/menigheter/nordberg/virksomhetsomrader/ velkommen-som-konfirmant/ungdomsarbeid-i-nordberg/lederkurs-for-eldreledere (13. juni 2019).

NRK. 2017. «1000 pilegrimer til Nidaros i år» (26. juli).

Ord, Jon og Mark Leather. 2011. «The Substance Beneath the Labels of Experiential Learning. The Importance of John Dewey for Outdoor Educators», Australian Journal of Outdoor Education 15(2), s. 13-23.

Pew Research Center. 2018. Being Christian in Western Europe. [online]. Tilgjengelig: http://www.pewforum.org/2018/05/29/being-christian-in-western-europe (13. juni 2019).

Pettersen, Margun. 2013. Pilegrimens syv nøkler [online]. Tilgjengelig: https://kirken. no/globalassets/bispedommer/stavanger/dokumenter/tema/pilegrim/ressurser/ pilegrimens-nokkelord.pdf (13. juni 2019).

Pilegrimssenter Granavollen. 2017. Den kulturelle skolesekken. [online]. Tilgjengelig: http://granavollen.pilegrimsleden.no/no/nyheter/den-kulturelle-skolesekken (13. juni 2019).

Pilegrimssenter Oslo. 2018. Konfirmantvandring. [online]. Tilgjengelig: http://oslo. pilegrimsleden.no/no/pilegrimspresten/konfirmantvandring (13. juni 2019).

Pilegrimsvandring i trosopplæringen. 2019a. Inspirasjonsark2.Barnevandringer. [online]. Tilgjengelig: https://ressursbanken.kirken.no/nb-NO/2017/pilegrimsvandringfor-konfirmanter (13. juni 2019).

Pilegrimsvandring i trosopplæringen. 2019b. Inspirasjonsark 3. Konfirmantvandringer. [online]. Tilgjengelig: https://ressursbanken.kirken.no/nb-NO/2017/ pilegrimsvandring-for-konfirmanter (13. juni 2019).

Pilegrimsvandring i trosopplæringen. 2019c. Inspirasjonsark 1. Den nasjonale pilegrimssatsingen og lokale vandringer. [online]. Tilgjengelig: https://ressursbanken.kirken. no/nb-NO/2017/pilegrimsvandring-for-konfirmanter (13. juni 2019). 
Pilegrimsvandring i trosopplæringen. 2019d. Inspirasjonsark 4. Pilegrimsvandring $i$ trosopplaringen. [online]. Tilgjengelig: https://ressursbanken.kirken.no/ nb-NO/2017/pilegrimsvandring-for-konfirmanter (13. juni 2019).

Schjelderup, Ariane B. og Øyvind Olsholt. 2013. Filosofi og etikk i barnehagen. Cappelen Damm Akademisk.

Utdanningsdirektoratet. 2018. Overordnet del av lareplanverket. [online]. Tilgjengelig: https://www.udir.no/laring-og-trivsel/lareplanverket/overordnet-del/ (13. juni 2019).

Utdanningsdirektoratet. 2017. Rammeplan for barnehagen. Etikk, religion og filosofi. [online]. Tilgjengelig: https://www.udir.no/laring-og-trivsel/rammeplan/ fagomrader/etikk-religion-filosofi/ (13. juni 2019).

Utdanningsdirektoratet. 2015. Generell del av læreplanen. [online]. Tilgjengelig: https:// www.udir.no/laring-og-trivsel/lareplanverket/generell-del-av-lareplanen/ (13. juni 2019).

Verdens Naturfond. 2018. Living Planet Report. 2018: Aiming Higher, WWF, Gland, Sveits

Vormeland, Solveig Tjernæs og Sofrid Leineb $\emptyset$ Seljås. 2018. «Kristuskransen med konfirmanter». I: Ekre, Eldbjørg Leineb $\emptyset$ (red): Jordvenn - venn med hele skaperverket, Oslo: IKO-Forlaget, s. 92-95.

Vårt Land. 2018. «Med føttene blir de kjent med røttene» (2. oktober). 